\title{
PROPOSALS FOR LEGISLATIVE PREPARATION AND TRAINING IN THE FIELD OF ENVIRONMENTAL PROTECTION

\author{
N. M. Peia
}

\author{
PhD Candidate Ninel M. Peia, \\ Deputy, Parliamentary Office no. 284, Electoral District 25 Ilfov \\ PhD Candidate "MIHAI VITEAZUL" National Intelligence Academy (Romania) \\ E-mail: ninelpeia@yahoo.com
}

\begin{abstract}
The assessment of environment legislation drafting is an essential component in the process of modern and sustainable planning to which the well-being of human society at global, regional and local level, is directly connected. Maintaining the balance between the two categories of legislative structures, the environment and environmental protection, contributes to providing an appropriate level of environmental goods and services, limiting the scale of environmental conflicts, streamlining institutional flows and maintaining a high standard of the sanogenesis state of the environment and, therefore, of the population.
\end{abstract}

Keywords: legislation, environmental protection, proposals, institutional, professional training, cooperation, education

\section{Introduction}

The future development of environmental legislation will focus on an integrated assessment of legislation drafting in advanced countries, a comparison with what we have and the improvement of the structure and operability of environmental infrastructures. In this sense, integration into international research networks, publishing the results in internationally-visible publications and the transfer of knowledge and work tools to the legislative environment, are the main modes of implementation thereof.

\section{Solving environmental problems through modern legislative proposals}

Legislative rules used in order to solve environmental problems should be increasingly categorical, drastic and exclusive, so that, finally, they might exclude intervention or totally remove the detrimental consequences of certain human activities ${ }^{1}$.

The enforcement, as of 2015, of the legislative provisions laid down by EU Directives imposes itself as a priority, and by enforcing EU regulations, industrial units can maintain market competitiveness through:

- the optimization of the operation of facilities by implementing the measures specified by the reference documents on the best available techniques specific to industrial activities, of which an important share belongs to the improvement of energy efficiency of the production processes;

- in the long term, the implementation of CCS technologies, involving the capture, transport and geological storage of $\mathrm{CO} 2$, especially applicable in the case of electricity producers and highly polluting industries;

Increasing the efficiency of technological processes will diminish the effects of this increase, but on the other hand reducing the assigned ceiling will lead to an increase in expenses per product ${ }^{2}$. This will impose:

\footnotetext{
${ }^{1}$ Eckhart Rehbinder, Democracy, Access to Justice and Environment at International Level, 2006, page 147

${ }^{2}$ Marinescu Daniela - Tratat de dreptul mediului (Environmental Law Treatise), Editura Universul Juridic (Universul Juridic Publishing House), Bucharest, 2007, page 93
} 


\section{N. M. Peia}

- The need for the development and implementation of an assessment and data collection system (reporting such data should be an obligation on the part of economic operators provided by the law);

- The study of the old organizational structure of the energy sector with companies based on primary (nuclear, hydro-, thermal) energy resources, developed on the basis of new technical possibilities: Tesla battery and renewable energy;

- The establishment of energy companies with mixed fuel structures requires the development of a new optimization study of the loading of power plants so that electricity generation costs should be minimum;

- As regards the certificate portfolio management, it must be properly assessed so as to minimize the impact of the price of certificates;

- It is necessary that the potential certificates available should not be "wasted" until year 2017, they should be used strictly for investments to reduce emissions in case of resuming the trade in these certificates;

- Proposals for legislative changes on establishing provisions in order to take over the EU-induced impact will be required, after year 2015;

- The non-enforcement or delay in adopting the recommended measures may have economic consequences that are hard to recover, which could lead to the start of an environmental crisis: diluval floods, desertification of deforested areas, etc.

\section{Proposals in the field of institutional environment}

EU Member States have the duty (at least morally) to implement the rules of law that create the framework for sustainable development and, at international level, this can be achieved through treaties, agreements and conventions in different areas of international law such as outer space law, maritime law, biodiversity conservation and protection law - which lay down the rules of the common heritage of mankind in institutional and legal terms.

Laws and normative acts tend to be prescriptive and contain detailed provisions regarding the organization and implementation of the issues being regulated, establishing the manners of control or indicating the location of the structures established in order to implement them. Laws and normative acts are structured on the basis of a separate approach to environmental sectors. This is also the case for Romania, which takes action through:

a) The Ministry of the Environment:

- granting logistic assistance to the Romanian Government, to central and local government institutions, non-governmental and academic organizations (institutions) in the activities implemented and promoted by our country through the institutional framework of the EU directives;

- implementation of the projects and programs in the "Environment" field,

- which provide the following activities:

- development and implementation of activities for the creation of the National Environmental Framework;

- assessment of negative risks for the biological and socio-economic components of the country;

- development and implementation of measures regulating the use of genetically modified organisms (GMOs);

- assessment of the technological needs and promotion of the implementation of biotechnologies, which do not pose risks to the environment and human health, and contribute to the sustainable economic development of the country;

- facilitating the creation of databases and of the information and monitoring system concerning the use of GMOs, participation in the Information Exchange Mechanism concerning GMOs, even in cases of accidental release into the environment;

- strengthening national capacity to address issues related to the environment; 


\section{N. M. Peia}

- promotion and implementation of activities targeting the sustainable use of biological resources;

- cooperation, promotion and implementation of activities, projects and programs provided by the Information Exchange Mechanism with regard to the GMOs, as well as other mechanisms and tools provided by EU directives;

- development of project proposals, project concepts, project documents, etc. And presenting them for funding to the national and international institutions competent in the field;

- implementation and facilitation of the activities for awareness and information of civil society, of specialists and decision makers.

b) The Ministry of Agriculture and Food Industry is the central agriculture and food industry body of the State and bears responsibility for the:

- sectoral monitoring, the control of the enforcement of legislation and of the standards pertaining to the use and management of pesticides and chemical fertilizers;

- testing of chemical and biological substances, and delivery of the licences for the import/export of pesticides and fertilizers, as well as keeping their records;

- analysis and quality control of pesticides and fertilizers, and monitoring their presence in the soil, fodder and agricultural products;

- ensuring the food security of the population in terms of quality, quantity and availability of agricultural products;

- monitoring the compliance of agricultural products certified in the field of agriculture and food industry with the requirements of the legislation in force;

- ensuring compliance with ecological restrictions in the agricultural and agroindustrial sectors.

c) The Ministry of Health is the central health body and bears responsibility for: services;

- quality assurance of public health and providing the full spectrum of medical

- developing policies and programs, draft laws and normative acts, standards on human health and the sanitary and epidemiological situation;

- implementation of human health and sanitary-epidemiological activity business management, carrying out sanitary control and monitoring.

Research in the field is also carried out in higher education institutions:

- Universities in the field (environment) in Romania;

- Universities of Medicine and Pharmacy;

- Agricultural Universities.

As regards the latter situation, the fields of biotechnologies developed in these institutions will probably be taken into account, which include non-traditional methodologies and techniques for plant breeding, namely:

- tissue culture;

- methods of transmission of the genetic material through the technology of merging protoplasm or recombinant deoxyribonucleic acid (DNA);

- vegetative regeneration of plants.

Within the research institutions, a series of laboratories and structures that undertake activities related to new biotechnologies must be in place.

\section{Integrated environmental professional training}

Areas in which the integrated training of the management staff in the environmental field is carried out;

- Knowledge of international languages necessary for environmental cooperation.

- Depending on needs, the training may include other areas necessary for the carrying out of tasks and missions (e.g. inter-institutional cooperation). 


\section{N. M. Peia}

The departments responsible for the professional training of employees of institutions/bodies with environmental responsibilities will establish their own systems for the control of the manner of organization and conduct of training of their own staff in the field of reference.

The departments responsible for the professional training of staff in the institutions/structures with environmental responsibilities will assess the level of employee training and the quality of the initial and continuous professional training provided within their own system.

Continuous professional training provides the main environment for cooperation in the process of implementation of the Integrated Training Concept.

Continuous professional training is carried out throughout the entire career, involving staff who have completed the initial training and who work in institutions/bodies with environmental responsibilities.

Continuous professional training is conducted through current training activities in the workplace and other types of training supplied by specialized providers or various institutions that have the necessary training capacity.

Continuous training in the workplace will be directed at specific issues related to amending the legislation and working procedures, the entry into force of new categories of technology and equipment, changes in the environmental status, as well as those regarding issues involving the specialization, improvement, updating and development of environmental knowledge and professional skills.

\section{Environmental cooperation}

In the reports of the environmental status of Romania, the following basic principles of international cooperation ${ }^{3}$ in the field of environment and sustainable development are identified:

- Strengthening of the institutional capacity through participation in international and bilateral agreements;

- Bringing national environmental legislation closer to the requirements of international conventions and EU legislation, in view of the accession to the European Union;

- Mobilizing financial and technical assistance for the implementation of national environmental policies.

Also, among the principles of environmental law established by the legislation in the field, two more main principles are mentioned:

- the polluter pays principle or the principle of cooperation ${ }^{4}$.

- the principle of prevention and that of protection.

As regards the principle of cooperation, international environmental law does not yet contain any general, universal rules, that would stipulate very clearly the cases in which the responsibility of states comes into question, these issues being more often inferred from such principles as: sic utere tuo (according to which states have an obligation to make sure that their activities within their national jurisdiction do not cause damage to the environment of other states), the principle of good neighbourliness (it is established that in environmental law neighbouring states may also be those that are separated by large expanses of water or land), the principle of protection of the common heritage of mankind.

In order for international liability for an ecological damage to be enaged, a number of conditions must be met, which are quite difficult to prove in practice, such as:

\footnotetext{
${ }^{3}$ Eckhart Rehbinder - Protection of the European Environment after the Treaty of Amsterdam, M Duțu, op. cit., page 35; the Council decides with regard to the proposals of the Commission after consulting the European Parliament, the Economic and Social Committee and the Committee of the Regions.

${ }^{4}$ Brief presentation: "Administrative Law - Administrative Contentious Law - Criminal Law", seminar held under the aegis of the European Commission, Bucharest, pages 24-27, May 2014
} 


\section{N. M. Peia}

a) identifying the perpetrator of the pollution (in order to grant them the capacity of liable party).

b) the existence of prejudice (of the ecological damage).

c) establishing a causal link between the criminalised act and the damage occurred.

It is admitted in particular that, given the complexity of the environmental factors, their protection is a highly technical sector. It has also been pointed out that, in the context of the ecological crisis that manifests itself worldwide, the rules set up for environmental protection $^{5}$ are still insufficiently and ineffectively enforced.

If, with regard to environmental protection at international level through other forms of legal liability, there is a rich jurisprudence and doctrine, criminal liability has been relatively little regulated at international level. As environmental criminal law begins to assert itself increasingly more as an autonomous branch of law, international environmental criminal law gradually emerges. However, there are a multitude of causes that are (still) in the way of this goal: the major differences between national criminal law systems, the mechanisms of distinct sanctioning, the principle of state sovereignty, of non-extradition of nationals, the principle of dual criminality, problems pertaining to extraneous crimes being within the reach of criminal law, the possibility for the legal person to be held criminally liable ${ }^{6}$.

\section{Introducing novelty in the environmental field through change}

Senior management in today's organizations are required to operate in a constantly changing environment, characterized by an increasingly higher competitiveness, by an unstable balance, with successes and setbacks through social adaptation.

Change should not be seen as an end in itself, but as a means to adapt to new conditions, to maintain or improve organizational competitiveness, performance and effectiveness.

For the success of the change process, it is important for each manager to identify staff who are innovators and to act, together with them, through constant motivation, communication and direct engagement for the creation of an attitude favourable to change in the staff that fall within the broader category of the silent majority. Regarding also the emotional and volitional attitude of the staff, we consider it important to highlight that they will have a sinuous evolution throughout the implementation of the change process.

The role of the human factor in the success of the organization's change and development process is extremely important. Moreover, change must also occur at the level of individual behaviour. It is known that behavioural changes are the most difficult to induce.

\section{Proposals for education on environmental issues}

In preschool classes, children become familiar with certain aspects of the environment. In early 2014, a comprehensive and well-thought ecological training system for elementary, primary and secondary schools, was introduced. The Ministry of Instruction rejected the option of a separate course on ecology. Instead, environmental matters have been integrated into the mandatory curricula of natural sciences (biology, chemistry, physics, geography) and other subjects (such as, "Man and Society", "Civic Education" and "Life Skills").

Methodic guidelines have been published. Optional curricula include "Environmental Education", "Human Ecology" and "Man and Nature".

\footnotetext{
${ }^{5}$ Mirela Gorunescu "Protecţia juridico-penală a mediului" ("Environmental Criminal Law Protection"), article published in the Journal "Dreptul" ("Law"), issue 10/2003, page 159

${ }^{6}$ Maria Magdalena Neagu "Ocrotirea dreptului fundamental al omului la un mediu sănătos prin mijloace de drept penal" ("Protecting the Human's Fundamental Right to a Healthy Environment by Criminal Law Means", $\mathrm{PhD}$ thesis, "Ştefan cel Mare” Academy, Chişinău, 2014, page 54
} 


\section{N. M. Peia}

Each school year begins with an ecology class. Such lessons are also organized on Earth Day in April. However in some schools special ecology lessons are held, with the support of NGOs.

Many higher education institutions include environmental subjects in their curricula for various subjects (botany, zoology, geography, chemistry). The Academy of Economic Studies has introduced special courses such as energetics and environment, environmental monitoring and assessment, environmental management, environmental insurance and environmental standards. The Agricultural University offers courses in ecology and environmental protection, ecotoxicology and agro-ecology. The State University of Bucharest has curricula for ecologists, environmental lawyers, meteorology engineers and hydrology engineers. Timişoara Polytechnic University (Universitatea Politehnică) has a course for engineers on environmental issues ${ }^{7}$.

There is no system of teacher training in the field of environmental protection. Some NGOs have organized environmental training courses for teachers as part of international projects.

In 2012 the former Ministry of Environment developed a draft law on environmental (ecological) education. The Ministries of Economy and Finance blocked the adoption of the law arguing that it might have considerable budgetary implications. The need for a law on ecological education is more urgent than ever. For example, it impedes interested secondary schools from acquiring the status of colleges specializing in ecology. Studies of environmental education or education for sustainable development are becoming more and more necessary.

\section{Proposals for a better legislative correlation at NATO and EU level}

By admitting that many of the environmental legislative issues specific to the region of operation are of a global and cross-border nature, Romania will continue to contribute to regional and international environmental initiatives aimed at solving these problems.

As part of its mandate, our country will support through investments the implementation of the agenda and of global (UNO and NATO) and regional (EU) agreements associated with the environment and sustainable development, including the Framework Convention on Climate Change, the Stockholm Protocol, the Convention on Biological Diversity, the Convention on Environmental Impact Assessment in a Transboundary Context and the Convention on Access to Information, Public Participation in Decision-making and Access to Justice in Environmental Matters ${ }^{8}$. Each of these Conventions may provide specific topics for environmental activities. Romania will support the countries in which they operate in order to include the commitments and provisions of these international environmental agreements.

To make sure that the strategic directions mentioned above are observed, our country will assign the resources necessary to the effective implementation of its Environmental Policy. Romania will have sufficient human resources to oversee the assessment and monitoring processes and to initiate and develop environmentally-oriented operations.

\section{Conclusion}

Romania does not have a tradition in terms of environmental protection, both the Administration and civil society being beginners in matters of environmental protection by comparison with the states with established democracies. The environment, often seen as a minor problem in Romania, is actually one of the most important European Union policies which has a decisive influence on all other Community policies. Romania needs to become

\footnotetext{
${ }^{7}$ Alexandre Charles Kiss, Current Trends and Possible Future Developments of Legislative Training in International Environmental Law, 2009, page 67

${ }^{8}$ http://eur-lex.europa.eu/LexUriServ/LexUriServ.do?uri=COM:2005:0218:FIN:EN:PDF
} 
aware and learn about environmental policies and rights in order to ensure a real integration and protection of the environment in Romania in the spirit of the European approaches.

The conclusions of the IPCC $^{9}$ (Intergovernmental Panel on Climate Change) reflect a consensus of scientists worldwide, are apolitical and are an equilibrium factor for the tumultuous political climate of climate change.

Climate change is the greatest environmental, social and economic threat. Scientific data show intense increases of the temperature of air and ocean waters, the melting of glaciers, extreme weather including unusual heat waves, floods, etc. These disturbances have a negative impact on ecosystems, human health, water resources, the agricultural sector, tourism, etc. At this moment these developments are determined by the increase in Europe of the average temperature by a degree and by 0.8 at global scale since the pre-industrial age ${ }^{10}$. It is estimated that a temperature increase by another degree will generate phenomena that will cause irreversible, catastrophic damage, and may even lead to the disappearance of presentday civilization.

"This work was funded by the contract POSDRU(SOP HRD)/159/1.5/S/141699, strategic project ID 141699, co-funded by the European Social Fund, through the Sectoral Operational Programme Human Resources Development 2007-2013"

\section{Bibliography}

1. Chertes Dan - Sebastian - „Unele aspecte privind protecţia penală a dreptului la un mediu sănătos" ("A Few Aspects Concerning the Criminal Law Protection of the Right to a Healthy Environment"), Revista Caiete de drept penal (Journal of Criminal Law Notebooks), Publishing House C.H. Beck, Bucharest, 2008

2. Eckhart Rehbinder - Democracy, Access to Justice and Environment at International Level

3. Daniela Marinescu - Tratat de dreptul mediului (Environmental Law Treatise), Universul Juridic Publishing House, Bucharest, 2007

4. Eckhart Rehbinder - Protection of the European Environment after the Treaty of Amsterdam, M Duțu, op. cit., page 35; the Council decides with regard to the proposals of the Commission after consulting the European Parliament, the Economic and Social Committee and the Committee of the Regions.

5. Brief presentation: "Administrative Law - Administrative Contentious Law - Criminal Law", seminar held under the aegis of the European Commission, Bucharest, pages 24-27, May 2014

6. Mirela Gorunescu - "Protecţia juridico-penală a mediului" ("Environmental Criminal Law Protection"), article published in the Journal "Dreptul" ("Law"), issue 10/2003

7. Maria Magdalena Neagu - "Ocrotirea dreptului fundamental al omului la un mediu sănătos prin mijloace de drept penal" ("Protecting the Human's Fundamental Right to a Healthy Environment by Criminal Law Means", PhD thesis, "Ştefan cel Mare” Academy, Chişinău, 2014

8. Alexandre Charles Kiss - Current Trends and Possible Future Developments of Legislative Training in International Environmental Law

* Annual Report 2013 (www.curia.europa.eu/jcms/jcms/Jo2_7000/)

* http://eurlex.europa.eu/LexUriServ/LexUriServ.do?uri=COM:2005:0218:FIN:EN:PDF

* http://www.ipcc.ch/organization/organization_history.shtml

* http://unfccc.int/essential_background/feeling_the_heat/items/2917.php

\footnotetext{
${ }^{9}$ http://www.ipcc.ch/organization/organization_history.shtml

${ }^{10} \mathrm{http}: / /$ unfccc.int/essential_background/feeling_the_heat/items/2917.php
} 
N. M. Peia 